\title{
Ethnocultural Space of Krasnoyarsk Krai: The Current State
}

\author{
Ksenia V. Reznikovaa, Natalia N. Pimenovaa ${ }^{a}$, \\ Anastasia V. Kistova ${ }^{\text {a, }}$, Maria A. Kolesnik ${ }^{\text {, }}$ \\ Natalia P. Koptseva ${ }^{a^{*}}$, Alexandra A. Sitnikova ${ }^{a}$, \\ Natalia N. Seredkina ${ }^{a}$, Yulia S. Zamaraeva ${ }^{a}$ \\ and Ksenia I. Petrova ${ }^{a}$ \\ ${ }^{a}$ Siberian Federal University \\ 79 Svobodny, Krasnoyarsk, 660041, Russia \\ ${ }^{b}$ Krasnoyarsk Art Museum named after V.I. Surikov \\ 36 Karl Marks Str. / 20 Parizhskoi Kommmuny Str., \\ Krasnoyarsk, 660049, Russia
}

Received 07.07.2019, received in revised form 02.08.2019, accepted 09.08.2019

The main features and challenges of the ethnocultural space of one of the largest and most varied in its ethnic composition regions of the Russian Federation are studied in the article based on research material of the current state of culture of the indigenous minorities of the north living in the territory of Krasnoyarsk Krai (the Selkups, the Nenets, the Enets, the Dolgans, the Nganasans, the Evenks, the Kets and the Yessey Yakuts).

The study is based on modern approaches to the consideration of the mechanisms of sociocultural changes, such as the concept of "cultural trauma" of the Polish sociologist Piotr Sztompka. The article is based on the results of numerous field studies conducted by the scientists of Siberian Federal University.

Preference of mass culture and replacement of traditional with pseudo-traditional are emphasized among the main challenges of the current state of the ethnocultural space of Krasnoyarsk Krai.

Keywords: ethnocultural space, Siberian Arctic, Krasnoyarsk Krai, Krasnoyarsk, culture of indigenous minorities, ethnocultural heritage, problems of ethnocultural heritage, sociocultural changes, cultural trauma.

Research area: art history; culturology.

(C) Siberian Federal University. All rights reserved

* Corresponding author E-mail address: decanka@mail.ru

ORCID: 0000-0003-3910-7991 (Koptseva); 0000-0003-1299-6741 (Zamaraeva); 0000-0002-1622-2797 (Sitnikova); 0000-0001-8194-7869 (Kolesnik); 0000-0002-9248-8810 (Seredkina); 0000-0002-0622-4465 (Pimenova); 0000-0002-5309-4616 (Kistova)

This work is licensed under a Creative Commons Attribution-NonCommercial 4.0 International License (CC BY-NC 4.0). 
Citation: Reznikova, K.V., Pimenova, N.N., Kistova, A.V., Kolesnik, M.A., Koptseva, N.P., Sitnikova, A.A., Seredkina, N.N., Zamaraeva, Yu.S., Petrova, K.I. (2019). Ethnocultural space of Krasnoyarsk Krai: the current state. J. Sib. Fed. Univ. Humanit. soc. sci., 12(8), 1552-1567. DOI: 10.17516/1997-1370-0464.

\section{Introduction}

The issues of preserving the original ethnic culture of indigenous minorities have been discussed for a long period of time and are still relevant. Nowadays, there are various options for the preservation and conservation of ethnocultural heritage in the world, and each country and region have the right to choose mechanisms that are most suitable for specific conditions. Krasnoyarsk Krai is one of the largest regions of the Russian Federation, uniting Arctic territories from the Far North to the southern regions, and one of the most diverse in its ethnocultural composition.

Indigenous minorities of the north stand out among the large number of indigenous peoples of the region, since great attention in the Krai is paid to their ethnocultural heritage. Due to the accumulated experience, the analysis of the current state and identification of the problems of the ethnocultural space of Krasnoyarsk Krai are possible based on the study of the culture of the indigenous minorities of the north living in the region.

A. Baranov (Baranov, 2016), A. A. Vereshchagina (Vereshchagina, 2015), Y. N. Ebzeeva, I. S. Karabulatova and D. A. Nakisbaev (Ebzeeva et al., 2018) study the trends of ethnic identity transformation among various ethnic groups, including migrants and indigenous peoples. The argumentation of the possibility of ethnic identity transformation into a multi-ethnic civic nation as a condition and possibility of ethnic revival, based on a higher level of social development, is presented in the studies by T.A. Davydova, M.M. Rostovtseva (Davydova, Rostovtseva, 2013) and N.I. Omorova (Omorova, 2014). A description of the criteria for the integrative model in Russia is presented in the study by E. A. Bagramov (2011). An analysis of the state's role in the formation and transformation of cultural and ethnic identity is presented in the studies by P. Kokaisl (2017) and L. Drobizheva (2017).

The reasons for the ethnic identity transformation among the indigenous minorities of the north are analyzed in the study by M. O. Makusheva (2017).

Such authors as N.P. Koptseva and V.I. Kirko (Koptseva, Kirko, 2014a; 2014b), as well as M. A. Kolesnik, N. M. Libakova and E. A. Sertakova (Kolesnik et al., 2016; Kolesnik et al., 2018) write about the practices of preserving ethnic identity of indigenous peoples inhabiting the north of Krasnoyarsk Krai. Articles by A.M. Ablazhey and 
C.R. Campbell (Ablazhey, Campbell, 2018), as well as E.M. Kuznetsova (2018) and V.P. Krivonogov (2017) are devoted to local identity transformations.

Researchers lay special emphasis on educational resources as the main factors influencing changes in the ethnic culture of indigenous peoples. Articles by M. A. Kolesnik, N. M. Libakova and E. A. Sertakova (Kolesnik, Libakova, Sertakova, 2018), as well as E. Nikiforova (Nikiforova, 2019), A. A. Sitnikova, N. N. Pimenova and A. I. Filko (Sitnikova, Pimenova, Filko, 2018) are devoted to this issue.

\section{Methods}

The main methods used in this article are field studies conducted in 2010-2014 in the northern territories of Krasnoyarsk Krai (in the areas with high concentration of such indigenous minorities as the Nenets, the Dolgans, the Selkups, the Yessey Yakuts, etc.), accompanied by interviewing indigenous respondents and analyzing research papers.

\section{Discussion}

The ethnocultural space of Krasnoyarsk Krai is heterogeneous: representatives of more than 150 ethnic groups live in its territory, and indigenous minorities of Krasnoyarsk Krai are among them (8 ethnic groups - the Dolgans, the Kets, the Nganasans, the Nenets, the Selkups, the Evenks, the Enets and the Chulyms). The present article focuses attention on the fact how indigenous minorities of the north (indigenous ethnic groups), which are a complex aggregate of interrelated components: traditional types of economy, decorative and applied arts, cuisine, medicine, traditional types of housing, language, traditional religious beliefs, customs and rituals, etc., are represented in the ethnocultural space of Krasnoyarsk Krai.

\section{Theoretical aspects of studying indigenous ethnic groups in the context of current social transformations}

At the present stage, an indigenous ethnic group is a very socially heterogeneous integrity (Ilbeikina, 2014; Kistova, 2014; Kolesnik, 2016; Libakova, Sertakova, 2015), and such concept of change as "cultural trauma", introduced by sociologist P. Sztompka gives an opportunity to explain the stratification of peoples called indigenous. $\mathrm{He}$ argues that cultural changes in society are uneven, since "the speed, rhythm and pace of social change are not the same in different areas of social life, where the cultural sphere is most inertial and is characterized by the slowest course of change and long- 
term preservation of the former conditions when a change has already happened" (Sztompka, 2001: 7). According to P. Sztompka, the critical factors influencing the fact that different social groups perceive traumas differently are "the availability of resources and social and cultural capital, that help to realize and define traumas, as well as actively counteract them" (Sztompka, 2001: 11). Therewith, not only the mechanisms of the undergoing changes are different, but also the nature of the reaction to the "cultural trauma": "The influence of the same potentially traumatic events (situations) may be qualitatively opposite for different groups. It can be destructive for some groups, useful and desirable for other groups and some groups just ignore it" (Sztompka, 2001: 13). In a traumatic situation, there are always central groups that actively experience it, and peripheral ones, displacing it, since it is insignificant for them. The colonial experience of the autochthonous population of numerous world territories, where they previously preserved almost unchanged traditional lifestyle, and collision of these societies with exogenous introduction of modernizing processes affected not only social, but cultural unity as well (Pimenova, 2012; Zamaraeva et al., 2015: 17). According to the model of sociocultural change, a trauma or a traumatic event (situation) in the form of colonization and lifestyle restructuring during longterm cultural dominance ("people influenced by a new culture, a socialized culture that they have "in their minds" or in semi-automatic "inclinations of their hearts" face the cultural environment where they find themselves" (Sztompka, 2001: 12)) launch the mechanism of reactionary cultural changes. It can be said that the difference in the internal groups of indigenous ethnic communities is a consequence of the specific features of different reaction mechanisms used by parts of society to cope with a trauma (Nevolko, 2011; Razumovskaya, 2014; Sertakova, 2013). The most dramatic changes in the sociocultural situation are observed in a case when a revolt, as a radical attempt of complete transformation of culture in order to comply with its new conditions, is chosen as a way of overcoming trauma. This method is chosen by a part of a modernized society, which enthusiastically takes up the position of the introduced culture, sees growth and development in the forthcoming way of life and, therefore, starts reorganizing their habitual way of life. In many respects, this corresponds to the representatives of the "protonation" group, which are mostly involved into the social institutions of modern society and sociocultural practices of the incoming culture the modern and postmodern practices, and are frequently the engines of new social processes in the ethnic community, in particular, an ethnic group reconstruction. Such a mechanism of change as innovation - a partial transformation of traditional culture 
in order to mitigate its inconsistencies with the dominant sociocultural reality - can lead to various, but not dramatic cultural changes. The "urban ethnic minorities" group mostly corresponds to the results of such a mechanism activity, and the rural population, which has significantly changed its lifestyle (has given up traditional crafts included in industrial practices and production) can also be included into it. The internal group "indigenous peoples" signifies of the least cultural changes within it. In this way, by choosing a passive mechanism for overcoming trauma (ritualism and retreatism), or due to the fact that this part of the autochthonous population of the colonized territories was in the field of the weak influence of the adopted culture (in particular, due to these settlements remoteness), these representatives of ethnic groups mostly preserved their original ethnic culture. The heterogeneity of ethnic communities that are called indigenous, indicates a complex unity of not only the society, but also ethnic culture within these internal social groups, about the cultural trauma experienced by these peoples for a long time, and the use of different ways to overcome it.

\section{Characteristic features of the culture of the indigenous peoples of the north of Krasnoyarsk Krai}

The environmental criterion of their perception of the world may be identified as the major most illustrative characteristic of the complex aggregate of the traditional culture of indigenous peoples. The environmental criterion is based on the absence of opposition between the northern man and the world, the man is an organic element of nature. The man lives according to the principles of nature: he does not kill more animals than it is necessary for food and life comfort; he necessarily helps his neighbor, since to leave in trouble in the harsh conditions of the Arctic equals to murdering; he shares what he has, which is also determined by the necessity for social cohesion in the harsh conditions; he uses herbs and animals for food and medical purposes, etc. Following these principles cannot lead to hoarding among the northern ethnic groups; on the contrary, the austerity of everyday life is typical for the indigenous peoples of the north.

A lot of representatives of indigenous peoples emphasize traditional activities, in particular reindeer herding, as the core of their cultural heritage: "The people will exist as long as the language exists, but in order to preserve the language, it is necessary to preserve traditional activities. Reindeer herding, hunting and fishing, in particular. And reindeer herding is the most important thing here. Since the Nenets culture is focused on deer, the culture of growing and processing domestic deer and 
its herding. Even all our tales and calendars are connected with deer" (a Nenets man). Researchers also emphasize the central role of traditional activities in preserving the culture of indigenous peoples: "Traditional nature management is the basis of the life activity of the indigenous peoples of the north, which is necessary for their existence" (Vladislavleva, 2011: 10, 11).

Strong correlation between the components of traditional culture ensures the uniformity of their development or, visa versa, decline and disappearance. Thus, decorative and applied art exists and develops in inextricable connection with traditional dwellings (decoration of chums), types of management (decoration of working tools), clothes (making of clothes and footwear decorated with patterns, etc.) and traditional beliefs (using some symbols and prohibiting for others, essential making of some attributes). As soon as these spheres of culture disappear, decorative and applied art disappear as well. The Selkups, who preserved only hunting as a traditional type of management, faced such situation, but still, there was a complete transition to the use of firearms as weapons, industrially made traps, "Burans", tourist tents, etc.

Despite the integrity, it is obvious that various components of the tangible and intangible cultural heritage of indigenous peoples have various degrees of transformation resistance. Thus, the best-preserved component of the indigenous peoples' culture is traditional cuisine. Almost $100 \%$ of the respondents know the names of ethnic cuisine dishes and their recipes, most respondents, regardless of their employment or nonemployment in the sphere of original nature management cook traditional dishes at least sometimes. Traditional customs and ceremonies (albeit in a reduced form after the extirpation of shamans) are also preserved, as well as decorative and applied arts (often in a stylized form) but, as for them, it is possible to talk about partial (ceremonies) or formal preservation (decorative and applied arts).

\section{Problems in developing the culture of indigenous minorities of the north of Krasnoyarsk Krai in the $21^{\text {st }}$ century}

Challenges typical for the preservation, dissemination and assimilation of the cultural heritage are, in any way, connected with the unique cultures of the indigenous peoples of the north in the modern world, their position between the traditional and historic lifestyle that underwent minor, almost unrecognizable changes over the centuries, and modern society with peculiar to it technical and technological discoveries that actively change everyday life. Indigenous peoples face a permanent dilemma: to preserve their unique historic culture, or to prefer a modern one, generally unified and 
homogeneous. And this dilemma can be considered through a number of individual problems, for instance, preference of the popular culture; replacement of traditional with pseudo-traditional, etc.

Mass culture preference is a problem affecting traditional types of dwellings, ethnic clothing, native language, religious beliefs, etc. Chums, baloks and golomo, traditional for a number of northern ethnic groups, are replaced by modular or log houses. The Selkups from settlement Farkovo can only show the place in their village where chums were located till the middle of the $20^{\text {th }}$ century. The chums are replaced not only by houses, but also by tourist tents, which are easier to use during the hunt. Chums are still used by herders belonging to other ethnic groups (for example, the Nenets and the Yessey Yakuts), but they use modern, but not traditional materials. Thus, instead of niuks (chum covers, made of buckskin) they use tarpaulin; the inner space of chum is covered with linoleum; traditional bedding is replaced by bed linen used by most of the country. In summer, parkas and malitsas are replaced with entsefaliitkas (khaki trouser suits, made of thick fabric, with a hood and a mosquito net covering the face); some ethnic groups (for instance, the Selkups) do not use traditional clothes, even in winter. Traditional types of footwear (mukluks and bokari) are either not used, or modernized using artificial materials such as nylon filaments, artificial fur as an inner layer, rubber sole, etc. (among the Nenets, the Dolgans, etc.).

There are also changes in household items and hunting and fishing tools. A bow with arrows and a hunting knife, traditional for the early $20^{\text {th }}$ century, were completely replaced by firearms; sledges were partially replaced by Burans, and traditional dugout boats (oblaskas, vetkas, etc.) were mostly replaced by motorboats. The ethnic language is no longer used in the everyday life of indigenous peoples and is replaced by Russian so much that regarding individual ethnic groups it is possible to say about the presence of two native languages, or even about Russian as their native one, while their ethnic language is studied at school along with English. In case of the Selkups, it is possible to talk about the ethnos division into three groups according to the degree of the Selkup language proficiency: representatives of one group know only a few words; the Selkups of another group know the language, but do not use it, preferring to think and speak only Russian; representatives of the third group are mostly the Selkups, engaged in traditional industries (hunting), they not only fluently speak their native language, but also actively use it during hunting and in their settlement.

The preference of the big society culture is also typical for the sphere of religious beliefs: indigenous peoples are Christianized; according to the respondents among the 
Selkups, the Nenets, the Dolgans, the Yessey Yakuts, the Evenks and the Kets, there are currently no shamans, all of them were massively exterminated in the $20^{\text {th }}$ century. Indigenous peoples have concerns that the preference of industrial culture may wipe away their traditional way of life, leaving only a visible shell from it. And this trend can also affect reindeer herding, called the ethnos-forming and ethnos-preserving activity by many people: "The deer will, of course, remain. And it will be like in Finland: reindeer moss is collected with bags, as for cows, and they drive cars. Deer will remain, but there will be no traditional lifestyle. Reindeer herder will be like a profession. Anyone can be a reindeer herder. And what is the traditional lifestyle then? This means that a person is surrounded by everything traditional, a person can make a balok, a boat, sledges and tools for catching fish, partridges and other animals" (a Nenets woman). The preference of mass culture is largely determined by a centralized ban on the traditional culture in the $20^{\text {th }}$ century (during the Soviet period). It concerned, for instance, the native languages of indigenous peoples: children from the tundra and taiga were not only taken to boarding schools, withdrawn from their natural language environment and immersed into the Russian-speaking one, but also prohibited to use their native language even in conversations among the representatives of one ethnic group. This ban in boarding schools also concerned traditional cuisine, clothing and medicine.

The problem of the lack of goal-setting, understanding the prospects for the traditional culture development and the desire to preserve and develop it can be found in the spheres of native language and decorative and applied art: young people who live in towns or large settlements do not want to study their ethnic language, and parents do not have desire to teach their children their native language, since it is more important to know Russian as the language of the country they live in, and English and Chinese as languages of international communication. One of the respondents, a Dolgan woman, engaged in decorative and applied art for commercial purposes, noted in the interview that due to the lack of desire to do something, there are a few persons like her: "I say that all of you can live like that. And there is silence immediately. What hinders you? To stay at home grumbling in the kitchen is one thing. I have no time to stay in the kitchen: I either sew or sell, I procure, and then I go to exhibitions, sometimes I sit and use my grey matter. ... Everything is in our hands."

Replacing traditional with pseudo-traditional is a problem typical for indigenous languages. In the case of the Selkups, the replacement lies in the fact that in Farkovo they teach not the local dialect of the native language, but the Tazovsky one. Therefore, 
schoolchildren's parents do not want their children to study a non-native language in the Selkup lessons. The Nenets and the Evenks also faced a language problem at school: these peoples have several dialects of their languages, while at schools they study literary Nenets and Evenki, created on the basis of one of the dialects and taking into account its features. According to the respondents, children who were brought up in the tundra before going to school and spoke only their native language there, have problems in learning a literary "native" language. Due to the imperfection of human memory and (or) loss of interest of native speakers, some historical legends have been lost. Thus, many respondents from the Turukhansk region (the Selkups and the Kets) told about the battle between the peoples that took place in the territory of their district in the early $20^{\text {th }}$ century. But in more than 100 years, there is no common opinion even concerning the question of who fought with whom: the Selkups with the Evenks, the Selkups with the Kets, or the Kets with the Evenks? The respondents said that there were literary works about this event, but not a single person could reproduce them, even approximately.

It is once again necessary to focus on the fact that, in general, the problems typical for the preservation, dissemination and assimilation of the cultural heritage can be reduced to a basic dilemma concerning the situation of traditional cultures in the modern world: it is necessary to prefer preservation of a unique culture (in fact, its conservation) or to choose the path of updating and modernizing of an ethnic group: "Indigenous minorities have to choose and balance between preserving traditions and accepting the values of modern Western societies, between particularism and universalism, following the traditional lifestyle and well-being, isolation and integration into nation states" (Yudin, 2011: 183). In other words, it is necessary to be focused on the past, on the historical cultural heritage, which is currently not sufficiently functioning in everyday life, or on the future, on techniques and technology that, on the one hand, simplify everyday life, but deprive it of its uniqueness, on the other. It is possible to say that this is the primary issue, the issue of the greater importance of culture as a historical heritage, or a society as an ethnic group living in the modern world. How is ethnicity manifested, can it be preserved in the modern conditions?

This is the respondents' opinion about the existing dilemma: "The longer civilization is not in contact with the peoples of traditional cultures, the longer the traditions preserve. The closer the civilization, the sooner people lose their language and their traditions.... After all, we either want people to live well, with all the benefits of civilization; or to preserve their culture and traditional lifestyle. As soon as a person 
realizes that it is possible to live in a modular house, and not to construct balok, kill deer and to cover balok with their skins, that's it, he will not do this anymore. It will be gradually forgotten. ... It turns out that there are two possible ideas about good life: the traditional one, where there the balok is good and there are a lot of deer, and a civilized one - with "Yamahas" and modular houses" (a Nenets woman); "I have already dealt with the benefits of civilization. They tempt. People got used to sewage, they don't want to freeze in the cold now, they don't want to carry water from somewhere afar. They want to have everything at hand. That is the reason why indigenous population abandon their traditional lifestyle. There is a large outflow of people from distant northern villages to towns (Dudinka or Norilsk), and from remote villages to the regional center" (a Nenets man).

Thus, the main problem typical for the preservation, dissemination and assimilation of cultural heritage is the lack of understanding where is the delicate balance between the necessity to preserve traditional culture and the importance of daily life modernization, in other words, what is the "indigenous nature" of indigenous peoples? How to preserve it, not forcing ethnic groups to live in the past? How the existence of a "modern traditional" culture of indigenous minorities of the north is possible? From the standpoint of the naturalistic paradigm of the concept of tradition, this dilemma (traditional or modern one) is without a solution. The solution can be found in the constructivist understanding of tradition, according to which "tradition is an infinitely changing dynamic reality created by the cultural and political elites of existing generations. In the constructivist sense, tradition is totally devoid of the unchangeable definable core" (Nesmelaya, 2012: 171). Based on the classical paradigm and without eliminating the opposition between the traditional and the modern, A.S. Nesmelaya transfers it from the level of intercultural relations into a separate culture, differentiating and contrasting the "traditional and innovative parts of culture. ... Culture is a two-component phenomenon. Tradition characterizes stereotyped experience and, by that, determines its significance and the period of its existence for a particular culture, and innovation characterizes its creative development" (Nesmelaya, 2012: 172).

Presence of traditional and modern components, which are rather easily defined and delimited, in the indigenous peoples' culture is associated with different rates of change taking place in them. We cannot say that the traditional component is constant: for example, modern materials come into use in the traditional clothes manufacture; new ingredients are included into the traditional cuisine recipes, etc. Changes within 
the culture take place at different rates: "The indigenous peoples of the north ... often experience difficulties under the current rapidly changing socio-cultural conditions and facing anthropogenic civilization. The model of their culture is based on the values conservation and preservation of the traditions, inherited from their ancestors. Traditional culture is a stable, non-dynamic culture, and its typical feature is the fact that the changes taking place in it are too slow and, therefore, virtually not recorded by the collective consciousness of this culture" (Nesmelaya, 2012: 170).

\section{Conclusion}

The ethnocultural space of Krasnoyarsk Krai is currently undergoing significant changes, including those connected with the processes taking place with the cultural heritage of the indigenous minorities of the north. The concept of social change by P. Sztompka, typical of the history of the indigenous peoples of Krasnoyarsk Krai, as the process of "cultural trauma" experienced by them, is used in this article. Reactions to a traumatic event can give rise to two possible scenarios for further development: aggravation of a traumatic situation and, as a result, the destruction of a culture, or an effective overcoming of this trauma through the reconstruction of a culture.

The main characteristics of the traditional culture of indigenous peoples, such as environmental criterion of their perception of the world; traditional activities, as the core of culture; the complex nature of the traditional culture components, etc. are described in the article. Relevant problems of the ethnocultural space of Krasnoyarsk Krai are connected with the current conflict of the traditional historic lifestyle and the modern society with its technical and technological discoveries that actively change everyday life. This conflict leads to the fact that indigenous peoples are constantly faced with a choice: to preserve their unique historic culture or to prefer modern, mostly unified and homogeneous one.

The major problems that arise as a result of experiencing "cultural trauma" are the lack of understanding of where is the delicate balance between the necessity to preserve traditional culture and the importance of modernizing everyday life; in other words, what is the "indigenous quality" of indigenous peoples and how to preserve it without forcing ethnic groups to live in the past; how the existence of the "modern traditional" culture of indigenous peoples of the north is possible? From the point of view of the naturalistic paradigm of understanding the tradition, this dilemma (traditional or modern one) is without a solution. It can be found in the constructivist understanding of tradition. The presence of traditional and modern components, which 
are rather easily defined and distinguished in the culture of indigenous peoples, is connected with different rates of changes taking place in them. We cannot say that the traditional component does not change, since changes take place within the culture, but at different rates.

\section{References}

Ablazhey, A.M., Campbell, C.R. (2018). Identity, Community and Belonging (on the Example of Kezhemsky \& Evenkiysky Municipal Districts of Krasnoyarsk Krai). In Journal of Siberian Federal University. Humanities \& Social Sciences, 11(4), $526-533$.

Bagramov, E.A. (2011). Protsessy globalizatsii v mire i grazhdanskaia i etnicheskaia identichnost' $\mathrm{V}$ usloviiah obshchestvennykh transformatsii $\mathrm{V}$ Rossii [Globalist Processes in the World and Civil and National Identity in the Conditions of Public Transformations in Russia]. In Vestnik Moskovskogo gorodskogo pedagogicheskogo universiteta. Seriya: Filosofskie nauki [Vestnik of Moscow City Pedagogical University. Series: Philosophical Sciences], 2(4), 63-74.

Baranov, A.V. (2016). Transformatsii regional'noi, etnicheskikh i konfessional'nykh identichnostei Krymchan v kontekste vossoedineniia Kryma i Rossii [Transformations of Regional, Ethnic and Confessional Identities of Crimeans in the Context of the Reunification of Crimea and Russia]. In Vestnik Permskogo nauchnogo centra UrO RAN [Bulletin of the Perm Scientific Center UB RAS], 5, 4-18.

Davydova, T.A., Rostovtseva, M.M. (2013). Vliianie modernizatsionnykh protsessov obshchestva na transformatsiiu etnicheskoi identichnosti [The Impact of the Modernization Processes of Society on the Transformation of Ethnic Identity]. In Sotsial'naia integratsiia $i$ razvitie etnokul'tur $v$ evraziiskom prostranstve [Social Integration and Development of Ethnocultures in the Eurasian Space], 1, 19-23.

Drobizheva, L. (2017). National Identity as a Means of Reducing Ethnic Negativism. In Mir Rossii, 26(1), 7-31.

Duguzheva, M. Kh. (2015). Natsional'nyi iazyk kak ob”ekt nematerial'nogo kul'turnogo naslediia korennykh malochislennykh narodov Severa [National Language as an Object of the Intangible Cultural Heritage of the Indigenous Peoples of the North]. In Yamal'skii vestnik [Yamal Herald], 4(5), 14-18.

Ebzeeva, Y.N., Karabulatova, I.S., Nakisbaev, D.A. (2018). The Problems of Transformation of the Personal Identity in a Modern Migrant. In Astra Salvensis, 6(1), $729-738$. 
Ilbeikina, M.I. (2014). Osobennosti visualno-antropologicheskih issledovanii indigennykh narodov [Specifics of Visual Anthropological Studies of Indigenous Peoples]. In Sovremennye problemy nauki i obrazovaniia [Modern Problems of Science and Education], 4, 594.

Khazankovich, YU.G. (2014). Kul'tura i literatura malochislennykh narodov Arktiki: "vlast' traditsii" [Culture and Literature of the North Indigenous Peoples of the Arctic: "the Power of Tradition"]. In Vestnik SVFU [Vestnik of North-Eastern Federal University], 1(11), 142-149.

Kistova, A.V. (2014). Formirovanie kommunikativnogo (interpretativnogo) etnographicheskogo metoda v sovremennom social'nom poznanii [The Formation of Communicative (Interpretative) Ethnographical Method in Modern Social Cognition]. In NB: Problemy politiki i obschestva [NB: Problems of Policy and Society], 11, 62-72. DOI: $10.7256 / 2306-0158.2014 .11 .1352$

Kokaisl, P. (2018). Transformation of the Ethnic Identity of the Rusin Minority in Slovakia. In Rusin, 52(2), 238-257.

Kokaisl, P. (2017). Cultural and Ethnic Transformation of Koreans in Central Asia. In Cesky Lid, 104(3), 339-359.

Kolesnik, M.A., Koptseva, N.P., Libakova, N.M., Luzan, V.S., Sergeeva, N.A., \& Sertakova, E.A. (2016). Economic Migration in Central Siberia and Ethnic Conflict Risks (Based on Krasnoyarsk Krai Analysis). In International Journal of Economics and Financial Issues, 6(5S), 104-108.

Kolesnik, M.A., Libakova, N.M., Sertakova, E.A. (2018). Art Education as a Way of Preserving the Traditional Ethnocultural Identity of Indigenous Minority Peoples from the North, Siberia and the Far East. In Novosibirsk State Pedagogical University Bulletin, 4, 233-247.

Kolesnik, M.A. (2016). Imaginary World as A Subject of "Eranos" Intellectual Group's Research in the 30-80s of the XX Century, In Journal of Siberian Federal University. Humanities \& Social Sciences, 1 (9), 79-90.

Koptseva N. P., Kirko V. I. (2014a). Ethic Identification of Indigenous People of the Siberian Arctic. In American Journal of Applied Sciences, 11(9), 1573-1577.

Koptseva, N.P., Kirko, V.I. (2014b). Post-Soviet Practice of Preserving Ethnocultural Identity of Indigenous Peoples of the North and Siberia in Krasnoyarsk Region of the Russian Federation. In Life Science Journal, 11(7), 180-185.

Krivonogov, V.P. (2017). Vliianie urbanizatsii na etnicheskie protsessy korennykh narodov srednei Sibiri [Influence of Urbanization on the Ethnic Processes of Indigenous 
Peoples of Middle Siberia]. In Spetsifika etnicheskikh migratsionnykh protsessov na territorii Tsentral'noi Sibiri v XX-XXI vekakh: opyt i perspektivy: sbornik materialov VI Mezhdunarodnoy konferentsii [Specifics of Ethnic Migration Processes in the Territory of Central Siberia in the $X X-X X I$ Centuries: Experience and Prospects: Collection of Materials of the VI International Conference], 31.

Kuznetsova, E.M. (2018). Ethnocultural Portrait of Russia: The Yessey Yakuts. The Life by the Lake (History and Culture of an Ethnic Group). In Journal of Siberian Federal University. Humanities \& Social Sciences, 11(4), 561-569.

Libakova, N.M., Sertakova, E.A. (2015). Formation of Ethnic Identiy of the Indigenous Peoples of the North in Arts and Crafts on the Example of Bone Carving. In Journal of Siberian Federal University. Humanities \& Social Sciences, 8(4), 750-768.

Makusheva, M.O. (2017). Transformation of Nenets Youth Identities in Different Cultural Environment. In Monitoring of Public Opinion: Economic and Social Changes, 4 (140), 54-65.

Nesmelaya, A.S. (2012). Etnicheskie traditsii, kul'tura korennykh malochislennykh narodov Severa i problemy ikh sokhraneniia [Ethnic Traditions, Culture of Indigenous Peoples of the North and the Problems of Their Preservation]. In Vestnik TGU. Gumanitarnye nauki. Pedagogika i psikhologiia [Tambov University Review. Series Humanities. Pedagogy and Psychology], 12(116), 169-172.

Nevolko, N.N. (2011). The Historiographical Review of the Scientific Literature of the Late $19^{\text {th }}$ to the First Decade of the $21^{\text {st }}$ Century Concerning the Problem of Ethnic Identification of the Khakass Ethnos. In Journal of Siberian Federal University. Humanities \& Social Sciences, 6 (4), 823-836.

Nikiforova, E. et al. (2019). Nomadic School: Problem of Access to Quality Education. In The International Conference Going Global through Social Sciences and Humanities. In Springer, Cham, 53-58.

Omorova, N.I. (2014). Globalizatsiia i transformatsiia etnicheskoi identichnosti diaspor [Globalization and the Transformation of Ethnic Identity of Diasporas]. In Vek globalizacii [Age of Globalization], 1 (13), 160-165.

Pimenova, N.N. (2012). Problemy obrazovaniia detei korennykh malochislennykh narodov Sibiri i Severa v Krasnoiarskom krae [Educational Problems of Childrens of Indigenous Peoples of Siberia and North of the Krasnoyarsk Region]. In Innovatsii $v$ nepreryvnom obrazovanii [Innovations in Continuous Education], 5(5), 12-18.

Razumovskaya, V.A. (2014). Kul'turnaia informatsiia: adaptatsiia i otstranenie $\mathrm{v}$ perevode [Cultural Information: Adaptation and Estrangement in Translation]. In 
Professional'no-orientirovannoe obuchenie inostrannim yazikam [Professionally Oriented Foreign Language Teaching], 8, 125-129.

Reznikova, K.V., Seredkina, N.N., Zamaraeva, Y.S. (2017). Perspective Formats for the Development of Decorative and Applied Art of the Indigenous Peoples of the Krasnoyarsk Territory. In Journal of Siberian Federal University. Humanities \& Social Sciences, 10(10), 1573-1593.

Sertakova,E.A.(2013). Sotsial'nyi konstruktivism kak kontseptsiia konstruirovaniia etnosa [Social Constructivism as the Concept of the Ethnos Construction]. In Sovremennye problemi nauki I obrazovania [Modern Problems of Science and Education], 6, 999.

Sitnikova, A.A., Pimenova, N.N., Filko, A.I. (2018). Pedagogical Approaches to Teaching and Adaptation of Indigenous Minority Peoples of the North in Higher Educational Institutions. In Novosibirsk State Pedagogical University Bulletin, 4, 26-45.

Sztompka, P. (2001). Sotsial'noe izmenenie kak travma [Social Change as Trauma]. In Sotsiologicheskie issledovaniia [Sociological Researches], 1, 6-16.

Vereshchagina, A.A. (2015). Transformatsiia etnicheskoi identichnosti v usloviiah postsovetskogo perioda razvitiia nezavisimykh gosudarstv [Transformation of Ethnic Identity in the Post-Soviet Period of Development of Independent States]. In Vestnik Baltiiskogo federal'nogo universiteta im. I. Kanta. Seriya: Filologiia, pedagogika, psikhologiia [IKBFU's Vestnik. Ser. Philology, Pedagogy, and Psychology], 5, 74-81.

Vladislavleva, T.B. (2011). Kul'turno-istoricheskoe nasledie kak resurs innovatsionnogo razvitiia korennykh malochislennykh narodov Severa [Cultural and Historical Heritage as a Resource for the Innovative Development of Indigenous Minorities of the North]. In Vestnik MGLU [MSLU's Vestnik], 2 (608), $9-20$.

Yudin, V.I. (2011). Gosudarstvennaia politika Norvegii v otnoshenii naroda saami: pravovye osnovaniia i sotsiokul'turnye protivorechiia [Norwegian Government Policy Towards the Sámi People: Legal Grounds and Sociocultural Controversies]. In Vlast' [The Authority], 12, 183-186.

Zamaraeva, Y.S., Kistova, A.V., Pimenova, N.N., Seredkina, N.N. (2015). Taymyr Reindeer Herding as a Branch of the Economy and a Fundamental Social Identification Practice for Indigenous Peoples of the Siberian Arctic. In Mediterranean Journal of Social Sciences, 6 (3), 225-232. DOI: 10.5901/mjss.2015.v6n3s5p225 


\title{
Этнокультурное пространство Красноярского края: современное состояние
}

\author{
К. В. Резникова ${ }^{a}$, Н.Н. Пименова ${ }^{\text {a }}$, А.В. Кистова ${ }^{a, ~}$, \\ М.А. Колесник ${ }^{a}$, Н. П. Копцева ${ }^{a}$, А.А. Ситникова ${ }^{a}$, \\ Н.Н. Середкина ${ }^{\text {a }, ~ Ю . С . ~ З а м а р а е в а ~}{ }^{\text {a }}$ К. И. Петрова ${ }^{a}$ \\ ${ }^{a}$ Сибирский федеральный университет \\ Россия, 660041, Красноярск, пр. Свободный, 79 \\ ${ }^{6}$ Красноярский художественный музей им. В. И. Сурикова \\ Россия, 660049, Красноярск, \\ ул. Карла Маркса, 36 / ул. Парижской Коммуньл, 20
}

В статье на материале изучения современного состояния культуры коренных малочисленных народов Севера, проживающих на территории Красноярского края (селькупы, ненцы, энџы, долганы, нганасаны, эвенки, кеты, ессейские якуты), рассматриваются основные особенности и проблемы этнокультурного пространства одного из самых крупных и разнообразных по этническому составу регионов Российской Федерации.

Исследование основывается на современных подходах к рассмотрению механизмов социокультурных изменений, в частности на концепџии «культурной травмы» польского сочиолога Петра Штомпки. Статья опирается на результаты многочисленных полевых исследований, проведенных учеными Сибирского федерального университета.

Среди основных проблем современного состояния этнокультурного пространства Красноярского края выделяются предпочтение массовой культуры и замена традиционного псевдотрадиционным.

Ключевые слова: этнокультурное пространство, Сибирская Арктика, Красноярский край, Красноярск, культура коренных малочисленных народов, этнокультурное наследие, проблемы этнокультурного наследия, социокультурные изменения, культурная травма.

Научная специальность: 17.00.00-искусствоведение; 24.00.00-культурология. 